\title{
ZnO nanoparticles: Crosslink between cytotoxicity on liver cell lines and In Vivo biosafety on different mice organs
}

\author{
Nahla Nabil Kamel ${ }^{1 *}$, Maha Zaki Rizk ${ }^{1}$, Walaa Gamal Hozayen², Abdel-Hamid Zaki Abdel-Hamid ${ }^{1}$ \\ ${ }^{1}$ Therapeutic Chemistry Department, National Research Centre, Giza, Egypt. \\ ${ }^{2}$ Biochemistry Division, Department of Chemistry, Faculty of Science, Beni-Suef University, Beni-Suef, Egypt and Department of Biotechnology and Life \\ Sciences, Faculty of Postgraduate Studies for Advanced Sciences (PSAS), Beni-Suef University, Beni-Suef, Egypt.
}

\begin{tabular}{l}
\hline ARTICLE INFO \\
\hline Received on: 03/09/2018 \\
Accepted on: 10/10/2018 \\
Available online: 07/03/2019 \\
\hline Key words: \\
ZnO nanoparticles, HepG2 \\
cells, HuH7, liver cancer, \\
cytotoxicity.
\end{tabular}

\begin{tabular}{l}
\hline ABSTRACT \\
\hline The wide applications of zinc oxide nanoparticles (ZnO NPs) in several biomedical aspects have raised many concerns \\
about their toxicity effects. This study aimed to explore the cytotoxic effect of different sizes (14, 30, and $50 \mathrm{~nm}$ ) of \\
ZnO NPs on liver cancer cell lines hepatoma G2 (HepG2), HuH7 cells (HuH7 hepatoma cells) versus normal cells \\
(THLE2 cells). Cytotoxicity, oxidative stress, and apoptosis were investigated. The results pointed out that the particle \\
size of $14 \mathrm{~nm}$ recorded the highest activity, whereas no cytotoxic effect was observed on THLE2. Also, oxidative stress \\
elicited a reduction in reduced glutathione with an increase in lipid peroxides and caspase-3. In addition, RT-PCR \\
revealed a significant up-regulation in caspase-3 gene expression. Histopathological investigation confirmed the \\
biosafety of the same particle size which revealed the least toxic effect on all mice organs (liver, kidney, lung, and \\
brain). In conclusion, this particle size of ZnO NPs could be useful in future therapeutic applications on liver cancer.
\end{tabular}

\section{INTRODUCTION}

Nanotechnology allows the manipulation of materials at nanoscale level (1-100 $\mathrm{nm})$, which enables precision engineering to control physicochemical properties of these nanoparticles (NPs), as well as their interactions with biological systems (Wang, 2008). Owing to their small size, high number per given mass, large specific surface area responses (Brown et al., 2002), concern regarding their fate in biological systems have raised a research in this field. Previous studies have indicated that NPs can penetrate cell nuclei and directly interfere with DNA structure, causing increased oxidative stress, induction of apoptosis, genotoxicity, and DNA damage (Ma et al., 2009; Wang et al., 2007). Inorganic NPs, including metal oxides, are promising materials for applications in medicine, such as cell imaging, biosensing, drug/gene delivery, and cancer therapy (Wu et al., 2011).

$\mathrm{ZnO}$ NPs have at least one dimension in the range of $1-100 \mathrm{~nm}$, a white powder nearly insoluble in water, with a unique

*Corresponding Author

Nahla Nabil Kamel, Therapeutic Chemistry Department, National

Research Centre, Giza, Egypt. E-mail: nahlanabel_nrc @ yahoo.com

This article was presented at the 5th Euro-Mediterranean Conference and Expo on Life Sciences, Pharma and Biomedicine (BioNat-V), Limassol, Cyprus. optical, electrical, and thermal performance has been widely used in the field of catalysis, sunscreen cosmetics, paint materials, and food packaging materials (Di Pasqua et al., 2008). The chemical and physical properties of nanoparticles have a strong influence on the way they interact with biological components or the environment (Dobrovolskaia and McNeil, 2007) and also on the way they move, accumulate, and clear in the body (Scheringer, 2008). Industrial food processing is intended to modify flavor, texture, and storage behavior by mixing with zinc oxide nanoparticles (ZnO NPs). After ingestion of food containing ZnO NPs, mechanical (chewing and peristalsis) and chemical (interaction with intestinal enzymes) processes reduce food into smaller components to maintain physiological processes. Some previous research has shown that $\mathrm{ZnO}$ NPs may cause cytotoxicity to several types of cells, such as osteoblast cancer cells (Nair et al., 2009), human bronchial epithelial cells (BEAS-2B) (Heng et al., 2011), human alveolar adenocarcinoma cells (Ahamed et al., 2011a), human hepatocytes, and embryonic kidney cells (Guan et al., 2012).

$\mathrm{ZnO}$ NPs with respect to their specific properties, such as their relative ease of production, ability to alter their physiochemical characteristics, their inherent toxicity against cancerous and bacterial cells, and ability to functionalize them 
with chemotherapeutic drugs and cancer targeting molecules, make them an appealing candidate for biomedical applications (Goharshadi et al., 2011; Moosavi et al., 2010).

Exposure to ZnO NPs leads to reactive oxygen species (ROS) generation and activation specific signal transduction pathways in target cells. Imbalance in the ROS production and antioxidant defense system of cells results in several different outcomes leading to cell death (Sharma et al., 2009). The oxidative stress mechanism of $\mathrm{ZnO}$ NPs could be attributed to the combination of more than one phenomenon, including generation of ROS on the surface of particles (Park et al., 2011), dissolution and release of $\mathrm{Zn}^{2+}$ ions in the culture media, and physical interaction of $\mathrm{ZnO}$ NPs with the membrane wall leading to the deformation and rupture of membrane (Li et al., 2008).

The distinct properties of NPs, such as small size, high number per given mass, large specific surface area, have aroused global concern regarding their fate in biological systems. Previous studies have indicated that NPs can penetrate cell nuclei of target cells and directly interfere with DNA structure, causing several adverse effects represented in increased production of ROS, induction of apoptosis, genotoxicity, and DNA damage (Wang et al., 2007).

Nanoparticles can translocate from entry portals into the lymphatic and circulatory systems and ultimately to body tissues and organs due to their small size. Some NPs can produce irreversible damage to cells by oxidative stress or/and organelle injury due to their composition and size causing severe cytotoxicity (Chernyshev et al., 2018). The distribution of these NPs to other organs, such as liver, spleen, brain, heart, and kidney may lead to dysfunction of these organs.

A previous study by Sharma et al. (2012) demonstrated that HepG2 cells exposed to $30 \mathrm{~nm} \mathrm{ZnO}$ nanoparticles for 12 hours showed a decrease in cell viability and the mode of cell death induced by $\mathrm{ZnO}$ nanoparticles was apoptosis. Also, Guan et al. (2012) assessed ZnO NPs cytotoxicity on human hepatocyte (L02) using $50 \mathrm{~nm}$.

Based on the previous information, this study was designed to demonstrate the impact of different particle sizes of $\mathrm{ZnO}$ NPs on normal and cancer cells to elucidate their cytotoxicity on target cells and their safety on normal cells which may help in the future application of $\mathrm{ZnO}$ NPs as promising therapeutic agents.

\section{MATERIALS AND METHODS}

\section{Preparation and characterization of nanoparticles}

Zinc oxide nanoparticles were synthesized using an aqueous solution of zinc nitrate or zinc acetate and a solution of potassium hydroxide or sodium hydroxide. The different solutions were prepared using deionized water while stirring and heating, respectively. The hydroxide solution was slowly added to the zinc salt solution at room temperature under vigorous stirring, which resulted in the formation of a white precipitate. The precipitate was centrifuged at $6,500 \mathrm{rpm}$ while cooling to $-10^{\circ} \mathrm{C}$ for 20 minutes. The resulted product was washed with distilled water several times followed by absolute alcohol. The obtained product was calcined at $500^{\circ} \mathrm{C}$ in an air atmosphere for 3 hours. The resulted nanoparticles were tested by TEM in order to evaluate the particle morphology; shape and size. The nanoparticles of zinc oxide were then redisposed in deionized water to give the requested concentrations (Hingorani et al., 1993).

\section{Experimental design}

\section{Cell culture}

Cell Line (HepG2, HuH7, and THLE2 cells) was obtained from American Type Culture Collection, cells were cultured using DMEM (Invitrogen/Life Technologies) supplemented with $10 \%$ FBS (Hyclone,), $10 \mu \mathrm{g} / \mathrm{ml}$ of insulin (Sigma), and 1\% penicillinstreptomycin. All of the other chemicals and reagents were from Sigma or Invitrogen. Plate cells (cells density $1.2--1.8 \times 10,000$ cells/well) in a volume of $100 \mu$ complete growth medium +100 $\mu 1$ of the tested compound per well in a $96-$ well plate for 24 hours before the MTT assay.

\section{Cell viability assay}

Viability of HepG2, HuH7, and THLE2 cells was assessed by the MTT assay as described by Mossman with some modifications (Ahamed et al., 2011b). Briefly, $1 \times 104$ cells/well were seeded in 96-well plates and exposed to varying concentrations of $\mathrm{ZnO}$ NPs for 24 hours. At the end of the exposure, the culture medium was removed from each well to avoid interference of $\mathrm{ZnO}$ NPs and replaced with new medium containing MTT solution $(0.5 \mathrm{mg} / \mathrm{ml})$ in an amount equal to $10 \%$ of culture volume and incubated for 3 hours at $37^{\circ} \mathrm{C}$ until a purplecolored formazan product developed. The resulting formazan product was dissolved in acidified isopropanol. Further, the 96well plate was centrifuged at 2,300 $\times g$ for 5 minutes to settle the remaining $\mathrm{ZnO}$ NPs. Then, a $100 \mu \mathrm{l}$ supernatant was transferred to other fresh wells of a 96-well plate, and absorbance was measured at $570 \mathrm{~nm}$ by a microplate reader (FLUOstar Omega, Cary, NC).

\section{Lipid peroxidation assay}

The extent of membrane LPO was estimated by measuring the formation of malondialdehyde (MDA) using the method of Ohkawa et al. (1979). MDA is one of the end products of membrane LPO. Briefly, a mixture of $0.1 \mathrm{ml}$ cell extract and $1.9 \mathrm{ml}$ of $0.1 \mathrm{M}$ sodium phosphate buffer ( $\mathrm{pH} 7.4)$ was incubated at $37^{\circ} \mathrm{C}$ for 1 hour. After the incubation mixture was precipitated with $5 \%$ TCA and centrifuged $(2,300 \times g$ for 15 minutes at room temperature) to collect the supernatant. Then, $1.0 \mathrm{ml}$ of $1 \%$ TBA was added to the supernatant and placed in the boiling water for 15 minutes. After cooling to room temperature, the absorbance of the mixture was taken at $532 \mathrm{~nm}$ and was converted to MDA and expressed in nmole MDA/mg protein using molar extinction coefficient of $1.56 \times 105 \mathrm{M}^{-1} \mathrm{~cm}^{-1}$. A reaction mixture devoid of cell extract served as control.

\section{Glutathione estimation}

GSH level was quantified using Ellman's (1959) method. Briefly, a mixture of $0.1 \mathrm{ml}$ of cell extract and $0.9 \mathrm{ml}$ of $5 \%$ TCA was centrifuged $\left(2,300 \times g\right.$ for 15 minutes at $\left.4^{\circ} \mathrm{C}\right)$. Then, $0.5 \mathrm{ml}$ of supernatant added into $1.5 \mathrm{ml}$ of $0.01 \%$ DTNB and the reaction was monitored at $412 \mathrm{~nm}$.

\section{Caspase- 3 assay enzyme}

Activity of caspase- 3 enzyme was measured in exposed and control cells using standard assay kit (BioVision, Inc.). Crude cell extract was prepared as described above. This assay is based on the principle that activated caspases in apoptotic cells cleave 
the synthetic substrates to release free chromophore p-nitroanilide (pNA), which is measured at $405 \mathrm{~nm}$. The pNA was generated after specific action of caspase-3 on tertrapeptide substrates DEVDpNA (Ahamed et al., 2010b; Berasain et al., 2005). The reaction mixture consisted of $50 \mu \mathrm{l}$ of cell extract protein $(50 \mu \mathrm{g}), 50 \mu \mathrm{l}$ of $2 \times$ reaction buffer (containing $10 \mathrm{mM}$ dithiothreitol) and $5 \mu \mathrm{l}$ of 4 $\mathrm{mM}$ DEVDpNA substrate in a total volume of $105 \mu \mathrm{l}$. The reaction mixture was incubated at $37^{\circ} \mathrm{C}$ for 1 hour and the absorbance of the product was measured using microplate reader (Synergy-HT, BioTek) at $405 \mathrm{~nm}$ according to the manufacturer's instruction.

\section{Total RNA isolation and quantitative real-time PCR analysis for Caspase-3}

Human liver cancer HepG2 cells were cultured in sixwell plates and exposed to $15 \mu \mathrm{g} / \mathrm{ml} \mathrm{ZnO} \mathrm{NPs} \mathrm{for} 24$ hours. At the end of the exposure, total RNA was extracted by RNeasy mini Kit (Qiagen, Valencia, CA) according to the manufacturer's instructions. Concentration of the extracted RNA was determined using Nanodrop 8000 spectrophotometer (Thermo-Scientific, Wilmington, DE) and the integrity of RNA was visualized on a $1 \%$ agarose gel using a gel documentation system (Universal Hood II, BioRad, Hercules, CA). The first strand of cDNA was synthesized from $1 \mu \mathrm{g}$ of total RNA by reverse transcriptase using M-MLV (Promega, Madison, WI) and oligo (dT) primers (Promega) according to the manufacturer's protocol. Quantitative real-time PCR was performed by QuantiTect SYBR Green PCR kit (Qiagen) using an ABI PRISM 7900HT Sequence Detection System (Applied Biosystems, Foster City, CA). Two microliters of template cDNA were added to the final volume of $20 \mu \mathrm{l}$ of reaction mixture. Real-time PCR cycle parameters included 10 minutes at $95^{\circ} \mathrm{C}$ followed by 40 cycles involving denaturation at $95^{\circ} \mathrm{C}$ for 15 seconds, annealing at $60^{\circ} \mathrm{C}$ for 20 seconds, and elongation at $72^{\circ} \mathrm{C}$ for 20 seconds. The sequences of the specific sets of primer for caspase-3 (forward: 5'-TGGTTCATCCAGTCGCTTTG-3' reverse: 5'-CATTCTGTTGCCACCTTTCG-3'), and $\beta$-actin (forward: 5'-CCTTCCTGGGCATGGAGTCCT-3' reverse: 5'-GGAGCAATGATCTTGATCTTC-3') used in this study are given in our previous publication (Ahamed et al., 2011a). Expressions of selected genes were normalized to the $\beta$-actin gene, which was used as an internal housekeeping control. All the real-time PCR experiments were performed in triplicate, and data were expressed as the mean of at least three independent experiments.

\section{Histopathological examination}

Male albino mice (105), weighing 20-25 g, were obtained from the animal house of National Research Centre. Animals were housed in cages kept at standardized conditions $\left(22^{\circ} \mathrm{C} \pm 5^{\circ} \mathrm{C}, 55 \%\right.$ $\pm 5 \%$ humidity, and 12 hour light/dark cycle). They were allowed free access to water and pelleted standard chow diet.

Histopathological examination was performed for assessment of cytotoxicity of different size of ZnO NPs in different organs in mice. After careful selection on the basis of health and inclusion criteria, animals were left for 1 week for acclimatization and were randomly divided into two main groups according to the following schedule:

G1: Control group (normal healthy animals) $(n=15)$.

G2: Animals orally administered different sizes of $\mathrm{ZnO}$ NP using a dose $(150 \mathrm{mg} / \mathrm{kg}$ BW) for 14 consecutive days as described by Sharma et al. (2012) $(n=45)$.
Organs were kept in $10 \%$ formaldehyde and then embedded in paraffin for histopathological examinations (Van Herck et al., 2001). After deparaffinization and dehydration, sections of kidney, lung, spleen, heart, and brain of $4 \mathrm{~mm}$ thickness were stained with Hematoxylin and Eosin (H\&E) and examined under the light microscope (Bancroft and Stevens, 1996). All histopathologic processing and assessment of specimens were performed by an experienced observer unaware of the identity of the sample being examined to avoid any bias.

\section{Ethical procedure}

All procedures related to animal care and treatments strictly adhered to the ethical procedures according to the Guide for Care and Use of Laboratory published by the US National Institute of Health policies and approved by Animal Care and Use of the Committee of National Research Centre (approval no:13-088).

\section{Statistical analysis}

All data were expressed as mean $\pm \operatorname{SD}(n=5)$. Statistical analysis was carried out by one-way analysis of variance (ANOVA), version 8, coupled with Costat Software Computer program, where unshared letters are significant at $p \leq 0.05$.

\section{RESULTS AND DISCUSSION}

\section{Physical characterization of $\mathrm{ZnO}$ NPs}

Physical characterization of ZnO NPs with sizes 14, 30, and $50 \mathrm{~nm}$ was examined by transmission electron microscopy (TEM) to assert their particle size. Results demonstrated the accuracy of preparation of the selected NPs which showed sizes (a) relatively close to $14 \mathrm{~nm}$, (b) close to $30 \mathrm{~nm}$, and (c) close to $50 \mathrm{~nm}$ (Fig. 1).

\section{Cytotoxicity of $\mathrm{ZnO}$ nanoparticles}

The cytotoxicity of $\mathrm{ZnO}$ NPs in HepG2, HuH7, and THLE2 cells with different sizes $(14,30$, and $50 \mathrm{~nm}$ ) was evaluated by MTT. These cells were exposed to ZnO NPs (0.01$100 \mu \mathrm{g} / \mathrm{ml}$ ) for 24 hours. The results for $\mathrm{IC}_{50}$ using the different particle sizes are demonstrated in Table 1. It could be concluded that the smallest size NPs induced the least toxic effect on normal cells and the highest effective toxic concentrations on cancer cells followed by the particle size of $50 \mathrm{~nm}$, while the highest toxicity on cancer cell lines was demonstrated using a particle size of $30 \mathrm{~nm}$.

The most important critical features of $\mathrm{ZnO}$ NPs are their selective toxicity toward cancerous cells in comparison with normal human cells which shows potential benefits of these NPs as new antitumor drugs. Cytotoxicity results are in agreement with published studies which reported that $\mathrm{ZnO}$ NPs significantly induce cytotoxicity to human glioma cells, and no major effect was observed on normal cells (Ostrovsky et al., 2009). In addition, $\mathrm{ZnO}$ NPs exhibited a preferential ability to kill human myeloblastic leukemia cells $\left(\mathrm{HL}_{60}\right)$ as compared with normal peripheral blood mononuclear cells (Premanathan et al., 2011). Hanley et al. (2008) also observed that ZnO NPs exhibit a strong preferential ability to kill cancerous T cells compared with normal cells. Selective killing of cancer cells by ZnO NPs may be of important clinical interest, as one of the greatest challenges 


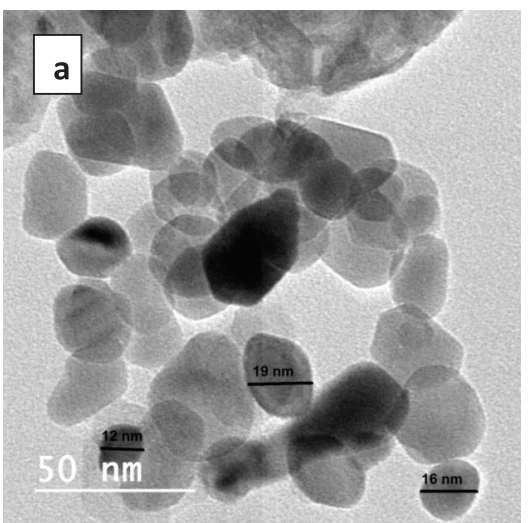

$\mathrm{ZnO}$ NPs $14 \mathrm{~nm}$

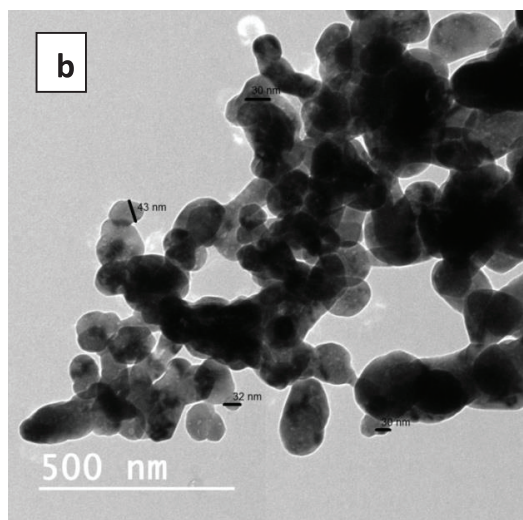

$\mathrm{ZnO} N \mathrm{NP} 30 \mathrm{~nm}$

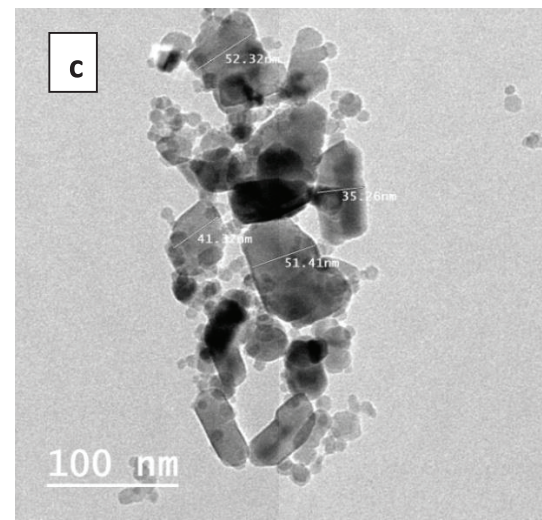

$\mathrm{ZnO}$ NPs $50 \mathrm{~nm}$

Figure 1. Characterization of $\mathrm{ZnO}$ NPs by TEM.

Table 1. Cytotoxic effect of $\mathrm{ZnO}$ NPs in HepG2, HuH7, and THLE2 cells as assessed by a MTT assay for 24 hours.

\begin{tabular}{cccc}
\hline \multirow{2}{*}{ ZnO NPs (nm) } & \multicolumn{3}{c}{ IC50 (Ug/ml) } \\
\cline { 2 - 4 } & HepG2 & HuH7 & THLE2 \\
\hline 14 & 0.048 & 0.17 & 202.9 \\
30 & 0.092 & 1.17 & 6.9 \\
50 & 0.1 & 0.22 & 12.7 \\
\hline
\end{tabular}

The data are presented as the mean $(n=5)$.

facing cancer chemotherapy is the inability of anticancer drugs to effectively distinguish between a normal cell and a cancer cell.

\section{Oxidative stress markers}

\section{Lipid peroxidation}

Lipid peroxidation was examined by measuring hydroperoxide concentration. Significant increase in hydroperoxide formation was observed in all compounds as evident from Figure 2. Oxidative stress has been suggested to play an important role in the mechanisms of toxicity of a number of nanoparticles

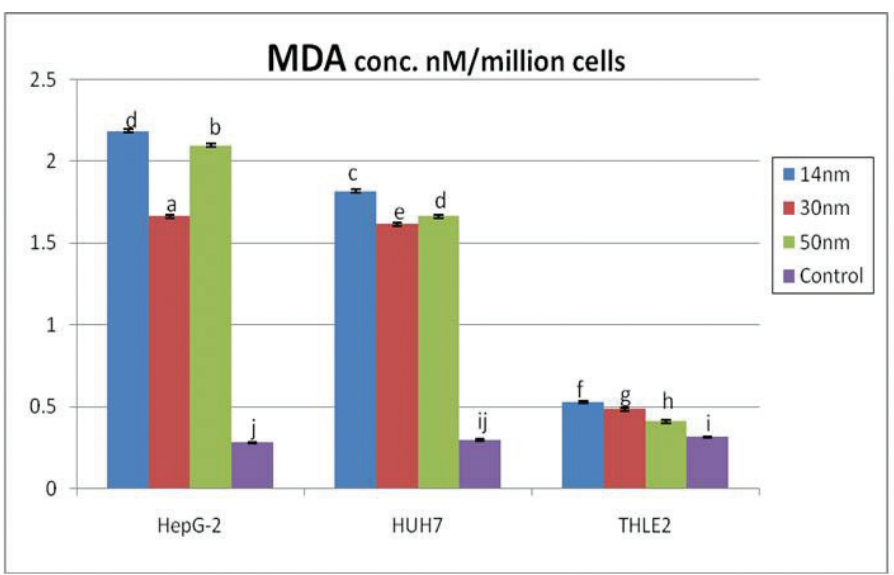

Figure 2. $\mathrm{ZnO}$ NPs-induced MDA level in different cell lines. Values are expressed as mean $\pm \mathrm{SD},(n=5)$. Statistical analysis is carried out using the SPSS computer program coupled with Co-Stat computer program (version 8), where unshared letters between groups are the significance value at $p \leq 0.05$. whether by the excessive generation of ROS or by depletion of cellular antioxidant capacity (Ahamed et al., 2010a; Wise et al., 2010). There has been an increase in biochemical, clinical, and epidemiological evidence that indicate the involvement of ROS and oxidative stress in various diseases, including cancer (Jomova and Valko, 2011). Our previous studies highlight that metal and metal oxide nanoparticles are able to induce ROS generation and oxidative stress in different types of cells (Ahamed et al., 2011a). In the present work, $\mathrm{ZnO}$ NPs were found to produce ROS, which consequently causes cell damage, as previously shown by Nel et al. (2006) and Park et al. (2010) that cell toxicity is induced by different nanoparticles due to oxidative stress.

\section{Glutathione reduced}

Cells exposed to ZnO NPs showed significant depletion in GSH level in all tested groups on both cancer cell lines, while no depletion was observed on normal cells as evident from Figure 3. These results were reinforced by the study of Sharma et al. (2009), who showed GSH level was depleted in human epidermal cells exposed to $\mathrm{ZnO}$ NPs. Furthermore, an increase in the formation of hydroperoxide compared with control, indicating an increase in

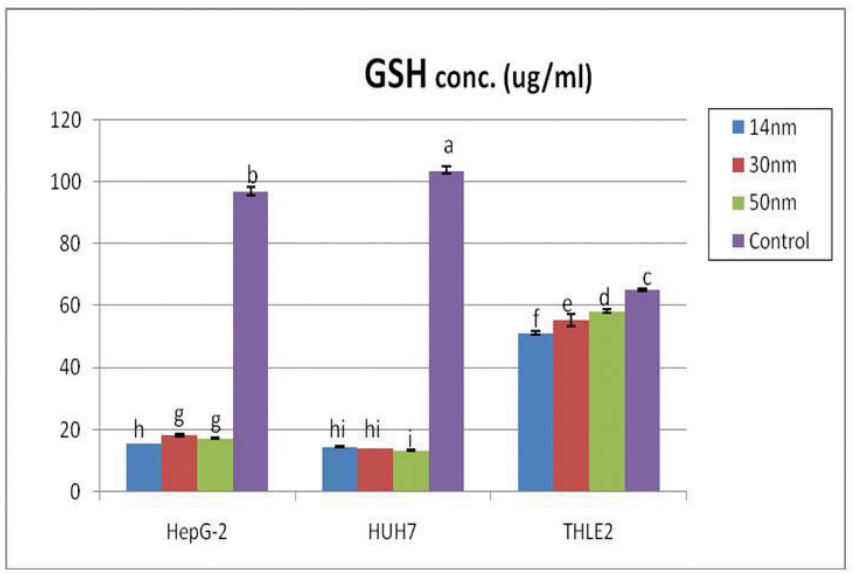

Figure 3. GSH level in different cell lines. Values are expressed as mean $\pm \mathrm{SD},(n=5)$. Statistical analysis is carried out using the SPSS computer program coupled with Co-Stat computer program (version 8), where unshared letters between groups are the significance value at $p \leq 0.05$. 
MDA after exposure to $\mathrm{ZnO}$ NPs which coincided with the results obtained by Sharma et al. (2009).

\section{Caspase-3 enzyme}

Cells exposed to $\mathrm{ZnO}$ NPs showed a significant increase in caspase 3 level revealing toxicity on both cancer cell lines with no effect on normal cell lines. ELIZA data are shown in Figure 4 and are confirmed by RT-PCR (Table 2). This could be explained by the fact that activated caspase- 3 is capable of autocatalysis, as well as cleaving and activating other members of the caspase family, which may subsequently cause rapid and irreversible apoptosis (Sánchez-Pérez et al., 2009). Also, in the same aspect, Akhtar et al. (2012) and Sharma et al. (2009) demonstrated upregulation in mRNA and higher activity of the caspase- 3 enzyme in liver cancer cells treated with ZnO NPs.

\section{Histopathological Findings}

Photomicrographs for histopathological study for doses $\leq 150 \mathrm{mg} / \mathrm{kg}$ BW were excluded since no significant effects on organ pattern were detected. Histopathological investigations on different organs using a dose of $150 \mathrm{mg} / \mathrm{kg} \mathrm{BW}$ with the different sizes are shown in Photomicrographs 1-8. The results showed that the histopathological disorders in liver, kidney, lung, and

Table 2. Effect of ZnO NPs on mRNA expression level of Caspase-3 in different cell lines.

\begin{tabular}{lccc}
\hline \multirow{2}{*}{ ZnO NPs } & \multicolumn{3}{c}{ Caspase-3 } \\
\cline { 2 - 4 } & HepG2 & HuH7 & THLE2 \\
\cline { 2 - 4 } & Conc. IU/ml & Conc. IU/ml & Conc. IU/ml \\
\hline $14 \mathrm{~nm}$ & $275.6 \pm 2.3^{\mathrm{a}}$ & $193.2 \pm 2.3^{\mathrm{b}}$ & $18.5 \pm 0.4^{\mathrm{h}}$ \\
$30 \mathrm{~nm}$ & $140.6 \pm 2.1^{\mathrm{d}}$ & $57.1 \pm 0.9^{\mathrm{f}}$ & $21.0 \pm 1.4^{\mathrm{g}}$ \\
$50 \mathrm{~nm}$ & $163.1 \pm 1.4^{\mathrm{c}}$ & $82.5 \pm 1.7^{\mathrm{e}}$ & $7.4 \pm 0.3^{\mathrm{j}}$ \\
Control Cells & $7.0 \pm 0.4^{\mathrm{j}}$ & $12.0 \pm 0.4^{\mathrm{i}}$ & $4.0 \pm 0.2^{\mathrm{k}}$ \\
\hline
\end{tabular}

Values are expressed as mean $\pm \mathrm{SD},(n=5)$. Statistical analysis is carried out using SPSS computer program coupled with Co-Stat computer program (version 8), where unshared letters between groups are the significance value at $p \leq 0.05$. brain revealed that size $14 \mathrm{~nm}$ induced the most promising nontoxic effect and no cytotoxic effects were observed in heart and spleen with any of particle sizes or dose used. A systematic study of the effect of different sizes, doses, and distribution is critical to the deep understanding of the toxicity mechanism. There are impacts factors affecting the properties of nanomaterials to differ significantly from other materials, including increased relative surface area and quantum confinement effect. This is in agreement with the report of Ben-Slama et al. (2015) who pointed out that the histopathological analysis of the kidney showed intratubular protein deposition but no significant glomerular changes. These findings were also concurrent with Al Rasheed et al. (2012) who declared that renal histopathological examination showed alteration of proteinaceous casts in the tubules and renal tubular dilatation in the $\mathrm{ZnO}-\mathrm{NP}$ treated rats. High dose of $\mathrm{ZnO}-\mathrm{NP}$ showed

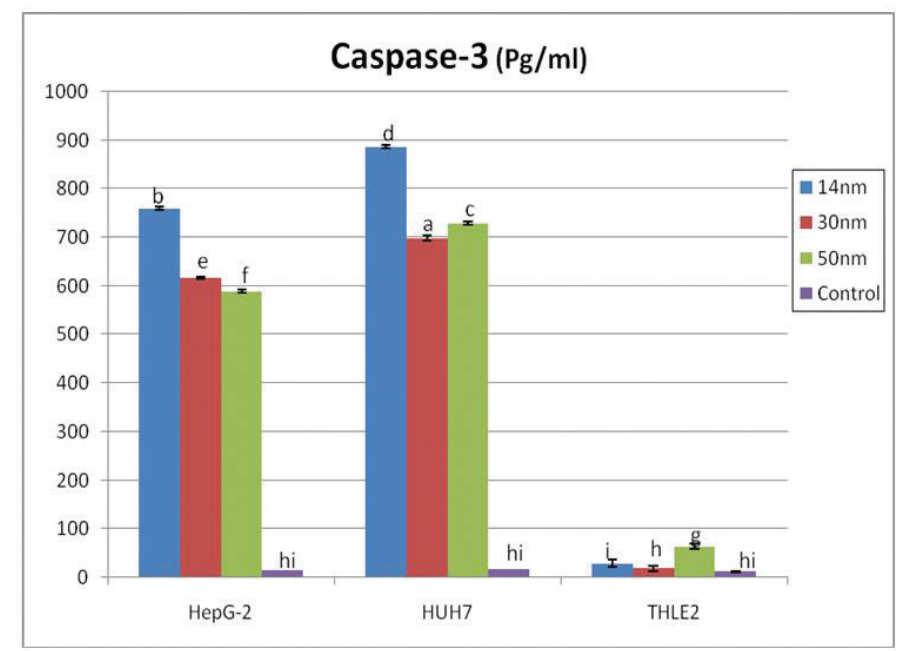

Figure 4. Caspase-3 enzyme in different cells. Values are expressed as mean \pm $\mathrm{SD},(n=5)$. Statistical analysis is carried out using the SPSS computer program coupled with Co-Stat computer program (version 8), where unshared letters between groups are the significance value at $p \leq 0.05$.
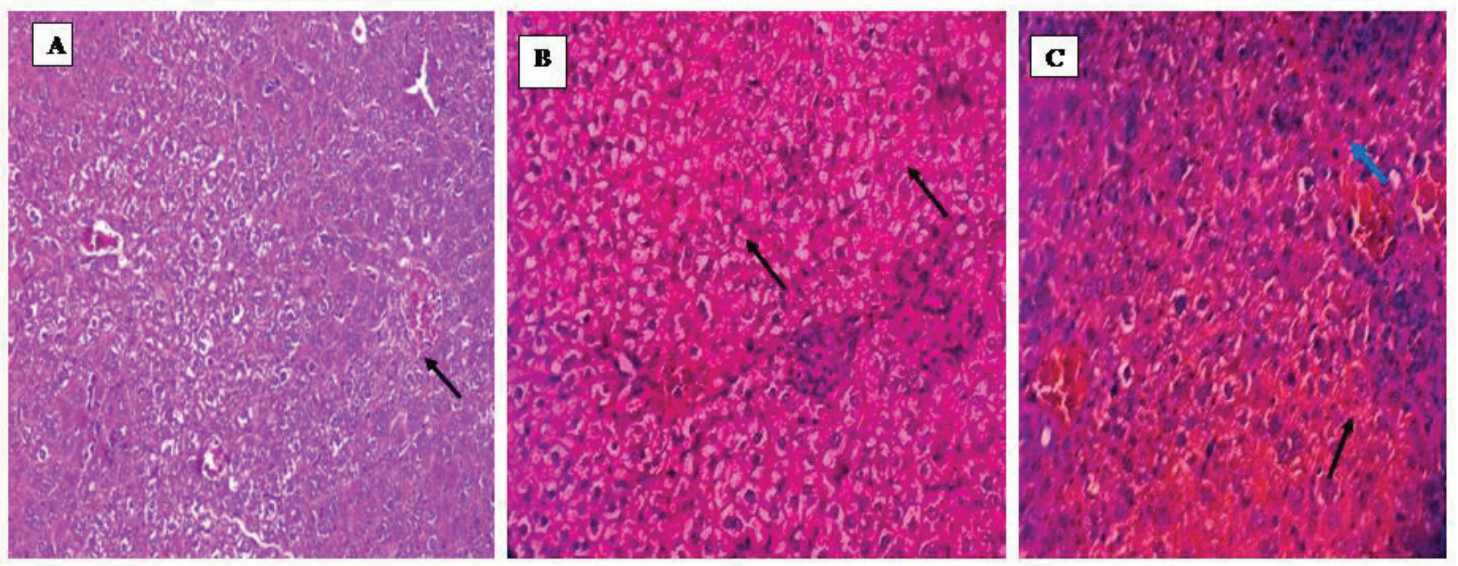

Photomicrograph 1. (A) Liver from the group $(14 \mathrm{~nm}, 150 \mathrm{mg} / \mathrm{kg}$ ) showed hepatic tissue with preserved (intact) lobular hepatic architecture and mild hydropic degeneration (black arrow) (H\&E, $\times 400)$. (B) Liver section from the group $(30 \mathrm{~nm}, 150 \mathrm{mg} / \mathrm{kg}$ ) showed preserved (intact) lobular hepatic architecture, hepatocyte with ballooning (red arrow), hydropic degeneration of hepatocytes (black arrow) and binucleated hepatocytes, congested blood vessels with $10 \%$ mild necrosis (H\&E, $\times 400$ ) (C) liver section from the group $(50 \mathrm{~nm}, 150 \mathrm{mg} / \mathrm{kg}$ ) showed hepatic tissue with binuclear hepatocytes (blue arrow) and sinusoidal dilatations vacuolation of hepatocytes along with hemorrhageand necrosis (black arrow) $(\mathrm{H} \& \mathrm{E}, \times 400)$. 


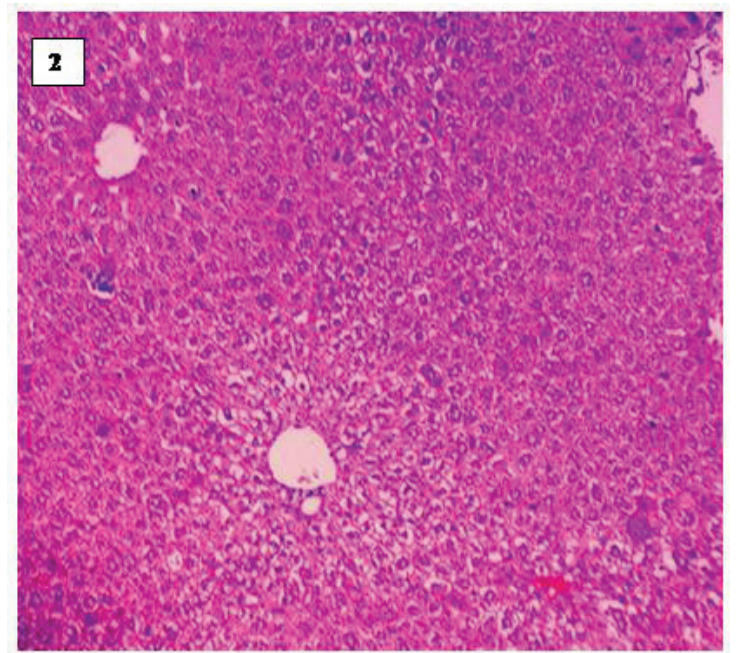

Photomicrograph 2. Liver section showed hepatic tissue with preserved (intact) lobular hepatic architecture and normal morphological appearance $(\mathrm{H} \& \mathrm{E}, \times 200)$.

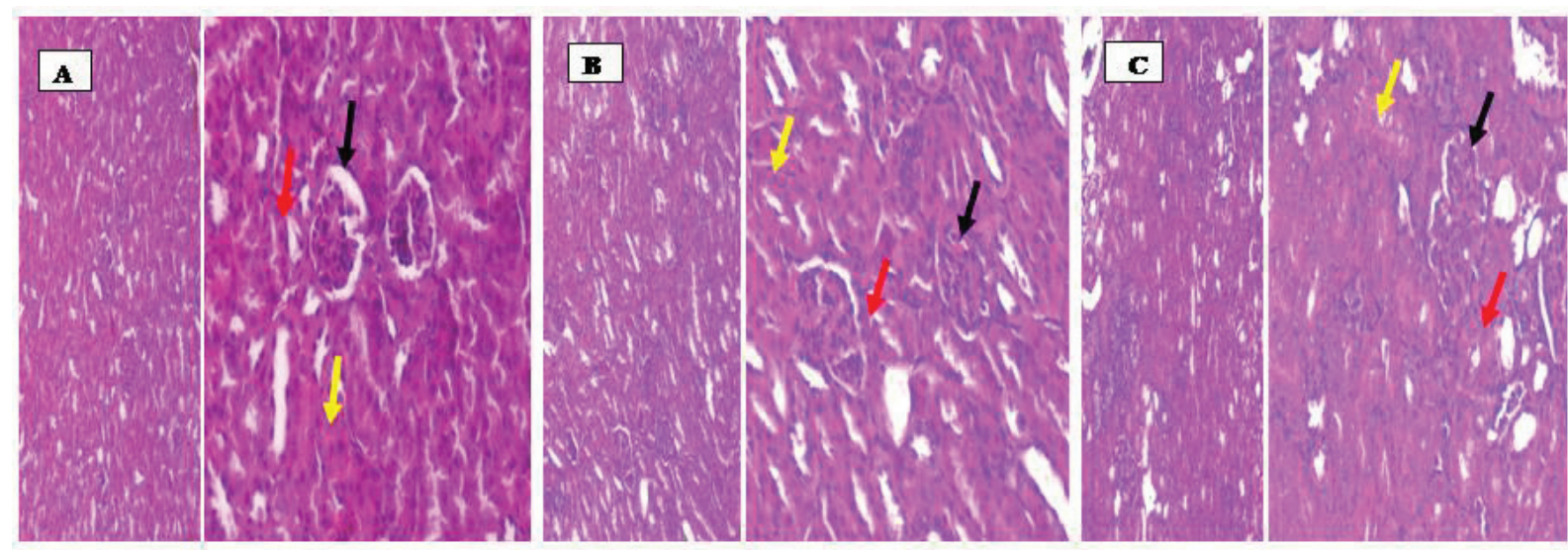

Photomicrograph 3. (A) Kidney section from the group $(14 \mathrm{~nm}, 150 \mathrm{mg} / \mathrm{kg}$ ) showed most of the corpuscles with high cellularity and obliterated capsular space (black arrow). Proximal convoluted tubules show destructed epithelial lining (red arrow), destructed epithelial lining of distal convoluted tubules (yellow arrow) (H\&E, $\times 200$, $\times 400)$. (B) Kidney section from the group $(30 \mathrm{~nm}, 150 \mathrm{mg} / \mathrm{kg}$ ) showed most of the corpuscles with very high cellularity and obliterated capsular space (black arrow). Proximal convoluted tubules show destructed epithelial lining (red arrow), destructed epithelial lining of distal convoluted tubules (yellow arrow) (H\&E, $\times 200, \times 400$ ). (C) Kidney section from the group $(50 \mathrm{~nm}, 150 \mathrm{mg} / \mathrm{kg}$ ) showed most of the corpuscles with very high cellularity and obliterated capsular space (black arrow). Proximal convoluted tubules show marked destructed epithelial lining (red arrow), destructed epithelial lining of distal convoluted tubules (yellow arrow) (H\&E, $\times 200, \times 400)$.

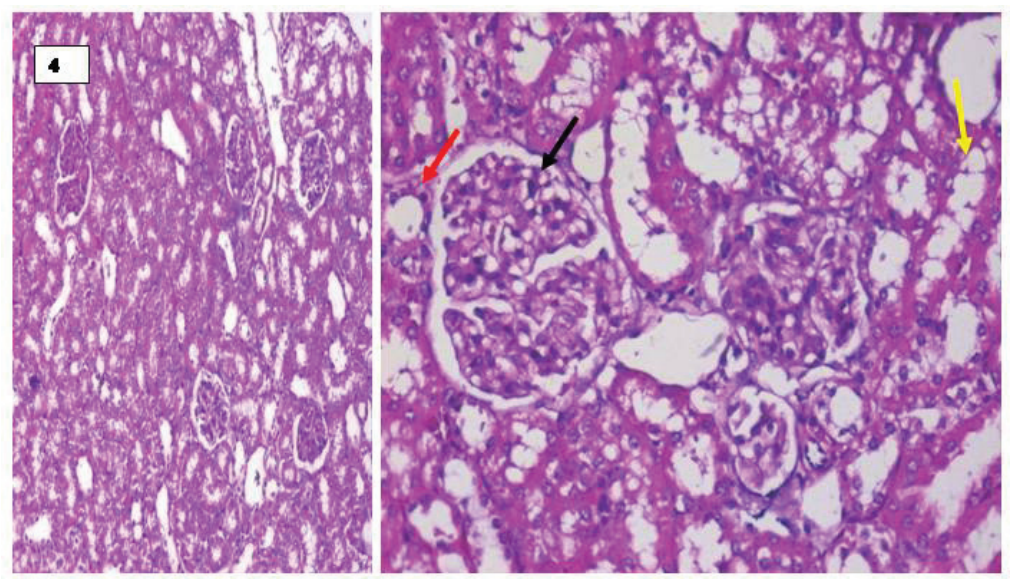

Photomicrograph 4. Kidney section from control group showed renal cortex of renal corpuscle with normal glomerulus (black arrow), the juxtaglomerular apparatus, the normal pattern of proximal convoluted (red arrow) and distal convoluted (blue arrow) tubules $(\mathrm{H} \& \mathrm{E}, \times 200, \times 400)$. 

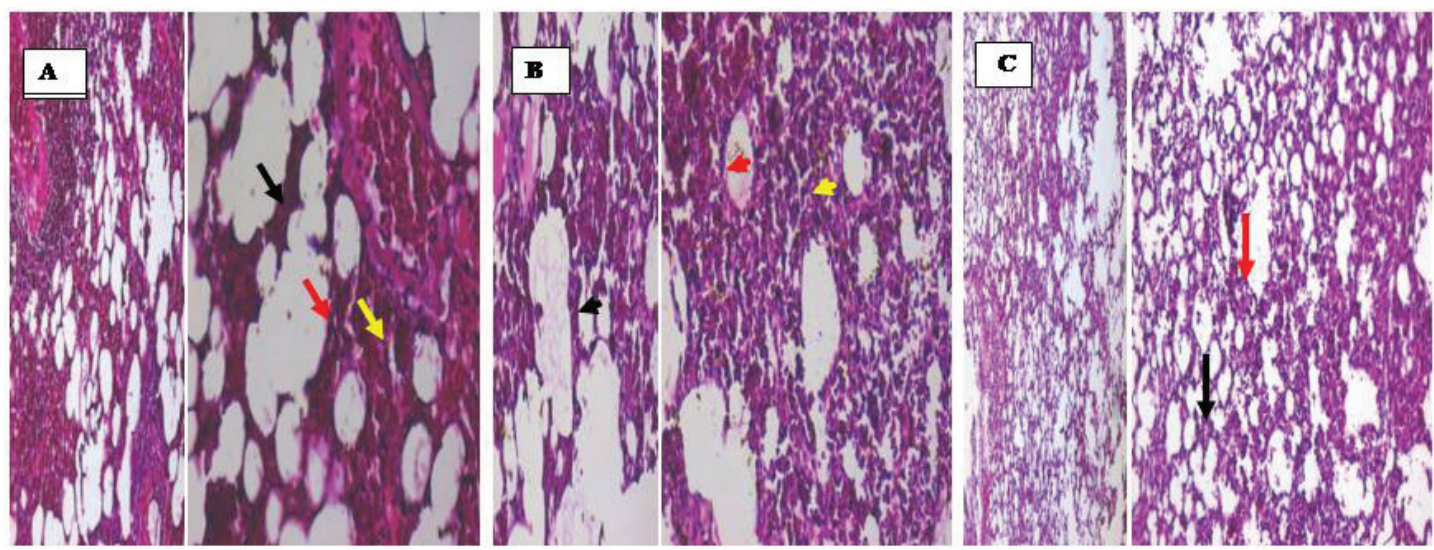

Photomicrograph 5. (A) Lung section from group (14 nm, $150 \mathrm{mg} / \mathrm{kg}$ ) showing the thick sections, having alveoli with thick intralveolar septum (back arrow), type I and type II pneumocytes were also clearly seen (red arrow), there is collection of lymphocytes (yellow arrow) (H\&E, $\times 200, \times 400$ ). (B) Lung section from group (30 $\mathrm{nm}, 150 \mathrm{mg} / \mathrm{kg}$ ) showing the very thick sections, having alveoli with thick intralveolar septum (back arrow), type I and type II pneumocytes were also clearly seen (red arrow), there is many collection of lymphocytes (yellow arrow) (H\&E, $\times 200, \times 400)$. (C) Lung section from the group $(50 \mathrm{~nm}, 150 \mathrm{mg} / \mathrm{kg}$ ) showing the thin sections of control having normal alveoli with thin intralveolar septum (back arrow), type I and type II pneumocytes were also clearly seen (red arrow) with scattered interstitial lymphocyte $(\mathrm{H} \& \mathrm{E}, \times 100, \times 200)$.

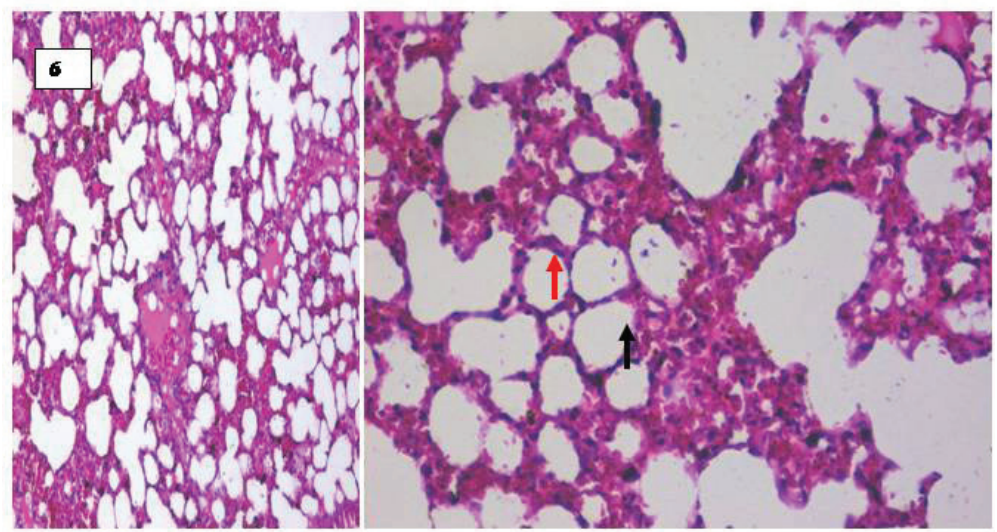

Photomicrograph 6. Lung section from control group showing the thin sections of control having normal alveoli with thin intralveolar septum (back arrow), type I and type II pneumocytes were also clearly seen (red arrow) (H\&E, ×200, ×400).
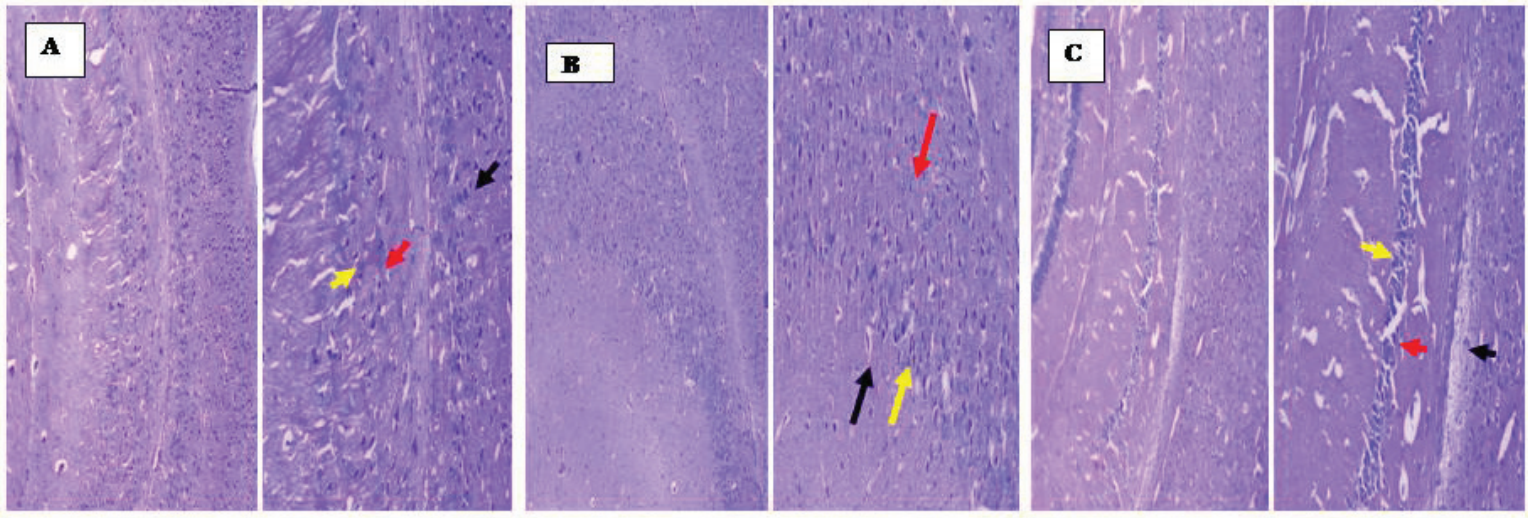

Photomicrograph 7. (A) Brain section of group (14 nm, $150 \mathrm{mg} / \mathrm{kg}$ ) of NCR, showed the cerebellum showed an atrophic molecular layer (black arrow), mildly atrophic and distorted granular layer (red arrow) and Purkinje layer (yellow arrow) and presence of thin closely packed small cells in the granular layer as well a large Purkinje cells in the Purkinje cell layer (H\&E stain, $\times 100, x \times 200)$. (B) Brain section of group $(30 \mathrm{~nm}, 150 \mathrm{mg} / \mathrm{kg}$ ) of NCR, showed the cerebellum showed a moderate size molecular layer (black arrow), mildly atrophic and distorted granular layer (red arrow) and Purkinje layer (yellow arrow) and presence of moderately closely packed small cells in the granular layer as well a large Purkinje cells in the Purkinje cell layer (H\&E stain, $\times 100, \mathrm{x} \times 200)$. (C) Brain section of group (50 nm, $150 \mathrm{mg} / \mathrm{kg}$ ) of NCR, showed the cerebellum showed well defined molecular (black arrow), granular layer (red arrow) and Purkinje layers (yellow arrow) and presence of numerous closely packed small cells in the granular layer as well a large Purkinje cells in the Purkinje cell layer (H\&E stain, $\times 100, \times 200)$. 


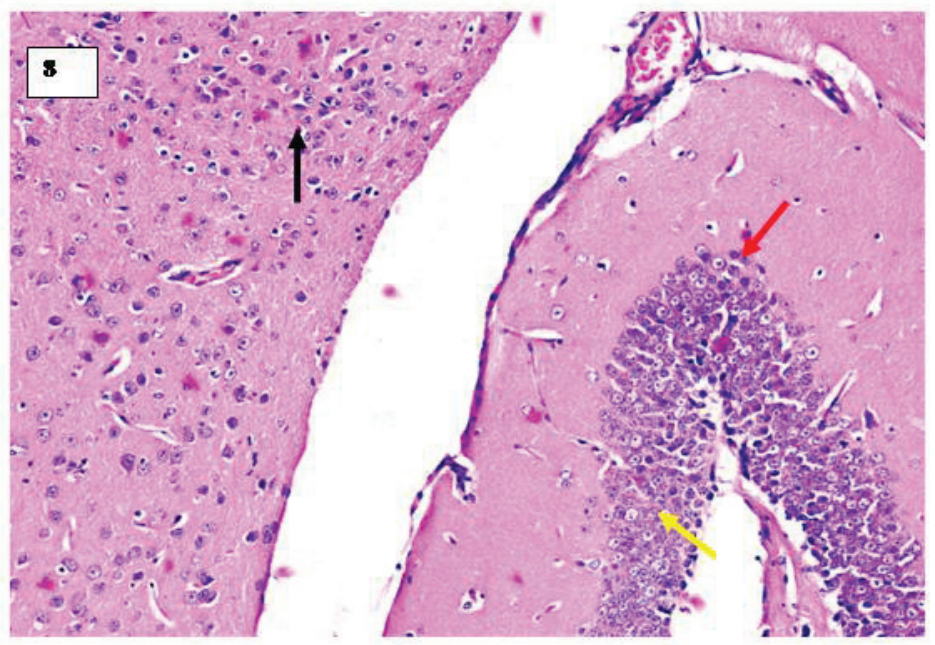

Photomicrograph 8. Brain section of a control group, showed the cerebellum of the group a showed normal histological features, illustrating a well defined molecular (black arrow), granular (red arrow) and Purkinje layers (yellow arrow) and presence of numerous closely packed small cells in the granular layer, as well a large Purkinje cells in the Purkinje cell layer. Or showing the normal structure of neuronal cells (H\&E stain, $\times 200)$.

massive atrophy and fragmentation of numerous glomeruli, the renal tubules showed epithelial exfoliation, degeneration, and necrosis. Some of the renal tubules showed casts in their lumina. The brain tissue showed neuronal cell degeneration and vacuoles were observed in the hippocampus, which is indicative of fatty degeneration in the hippocampus. In the lung tissues, inflammatory cells, foamy cells, and granulomatous lesions were observed in TiO2 NPs treated mice (Xu et al., 2013). Park et al. (2011) reported that granulomatous lesions were found in the bronchiole and alveoli of the lung after 14 days $\mathrm{TiO}_{2} \mathrm{NPs}$ treatment $(5,20$, and $50 \mathrm{mg} / \mathrm{kg}$ ) in mice.

The observed cytotoxicity of Zinc oxide nanoparticles on cancer cells is explained by the fact that these NPs typically have neutral hydroxyl groups attached to their surface, which plays a key role in their surface charge behavior. In the aqueous medium and at high $\mathrm{pH}$, the chemisorbed protons $\left(\mathrm{H}^{+}\right)$move out from the particle surface leaving a negatively charged surface with partially bonded oxygen atoms $\left(\mathrm{ZnO}^{-}\right)$. At lower $\mathrm{pH}$, protons from the environment are likely transferred to the particle surface, leading to a positive charge from surface $\mathrm{ZnOH}_{2}^{+}$groups. The isoelectric point indicates that $\mathrm{ZnO}$ nanoparticles will have a strong positive surface charge under physiological conditions. Given that cancer cells frequently contain a high concentration of anionic phospholipids on their outer membrane and large membrane potentials, interactions with positively charged $\mathrm{ZnO}$ nanoparticles are expected to be driven by electrostatic interactions, thereby promoting cellular uptake, phagocytosis, and ultimate cytotoxicity.

\section{CONCLUSION}

It could be concluded that the smallest size NPs (14 nm) induced the least toxic effect on normal cells and the highest effective toxic concentrations on cancer cells followed by the particle size of $50 \mathrm{~nm}$, while the highest toxicity on cancer cell lines was demonstrated using the particle size of $30 \mathrm{~nm}$. The marked difference in cytotoxicity between cancer cells and normal cells suggests an exciting potential for ZnO NPs as novel promising alternatives to cancer therapy.

\section{ACKNOWLEDGMENTS}

The authors would like to thank Prof. Dr. Essam Rashwan for his support during the in vitro studies.

\section{CONFLICT OF INTEREST}

There is no conflict of interest.

\section{FUNDING}

The research is funded by the National Research Centre as a grant for Ph.D. Thesis.

\section{REFERENCES}

Ahamed M, Akhtar MJ, Raja M, Ahmad I, Siddiqui MK, AlSalhi MS, Alrokayan SA. ZnO nanorod-induced apoptosis in human alveolar adenocarcinoma cells via p53, survivin and bax/bcl-2 pathways: role of oxidative stress. Nanomedicine, 2011a; 7:904-13.

Ahamed M, Akhtar MJ, Siddiqui MA, Ahmad J, Musarrat J, Al-Khedhairy AA, AlSalhi MS, Alrokayan SA. Oxidative stress mediated apoptosis induced by nickel ferrite nanoparticles in cultured A549 cells. Toxicology, 2011b; 283:101-8.

Ahamed M, AlSalhi MS, Siddiqui MKJ. Silver nanoparticle applications and human health. Clin Chim Acta, 2010a; 411:1841-8.

Ahamed M, Posgai R, Gorey TJ, Nielsen M, Hussain S, Rowe J. Silver nanoparticles induced heat shock protein 70 , oxidative stress and apoptosis in Drosophila melanogaster. Toxicol Appl Pharmacol, 2010b; 242:263-9.

Akhtar MJ, Ahamed M, Kumar S, Khan MM, Ahmad J, Alrokayan SA. Zinc oxide nanoparticles selectively induce apoptosis in human cancer cells through reactive oxygen species. Int J Nanomedicine, 2012; 7:845-57.

Al Rasheed N, Abdel Baky NA, Al Rasheed N, Shebly W, Ahmed AM, Faddah LM. Effect of vitamin $\mathrm{E}$ and $\alpha$-lipoic acid on nano zinc oxide induced renal cytotoxicity in Rats. Afr J Pharm Pharmacol, 2012; 6:2211-23.

Bancroft JD, Stevens A. Theory and practice of histological techniques. 4th edition, Churchill Livingstone, London, UK, p 163, 1996.

Ben-Slama I, Mrad I, Rihane N, El Mir L, Sakly M, Amara S. Sub-acute oral toxicity of zinc oxide nanoparticles in male rats. J Nanomed Nanotechnol, 2015; 6:1-6.

Berasain C, Garcia-Trevijano ER, Castillo J, Erroba E, Santamaria M, Lee DC. Novel role for amphiregulin in protection fromliver injury. J Biol Chem, 2005; 280:19012-20. 
Brown JS, Zeman KL, Bennett WD. Ultrafineparticle deposition and clearance in the healthy and obstructed lung. Am J Respir Crit Care Med, 2002; 166(9):1240-7.

Chernyshev VV, Zakharenko AM, Ugay SM, Hien TT, Hai LH, Kholodov AS, Burykina TI, Stratidakis AK, Mezhuev Ya O, Tsatsakis AM, Golokhvast KS. Morphologic and chemical composition of particulate matter in motorcycle engine exhaust. Toxicol Rep, 2018; 5:224-30.

Di Pasqua AJ, Sharma KK, Shi YL, Toms BB, Ouellette W, Dabrowiak JC, Asefa T. Cytotoxicity of mesoporous silica nanomaterials. J Inorg Biochem, 2008; 102:1416-23.

Dobrovolskaia MA, McNeil SE. Immunological properties of engineered nanomaterials. Nat Nanotechnol, 2007; 2:469-78.

Ellman GI. Tissue sulfhydryl groups. Arch Biochem Biophys, $1959 ; 82: 70-7$

Goharshadi EK, Abareshi M, Mehrkhah R, Samiee S, Moosavi M, Youssefi A, Nancarrow P. Preparation, structural characterization, semiconductor and photoluminescent properties of zinc oxide nanoparticles in a phosphoniumbased ionic liquid. Mat Sci Semicon Proc, 2011; 14:69-72.

Guan R, Kang T, Lu F, Zhang Z, Shen H, Liu M. Cytotoxicity, oxidative stress, and genotoxicity in human hepatocyte and embryonic kidney cells exposed to $\mathrm{ZnO}$ nanoparticles. Nanoscale Res Lett, 2012; $7: 602$

Hanley C, Layne J, Punnoose A, Reddy KM, Coombs I, Coombs A, Feris K, Wingett D. Preferential killing of cancer cells and activated human T cells using ZnO nanoparticles. Nanotechnology, 2008; 19:295103.

Heng BC, Zhao X, Xiong S, Ng KW, Boey FY, Loo JS. Cytotoxicity of zinc oxide ( $\mathrm{ZnO}$ ) nanoparticles is influenced by cell density and culture format. Arch Toxicol, 2011; 85:695-704.

Hingorani S, Pillia V, Kumar P, Multani MS, shah DO Microemulsion mediated synthesis of zinc-oxide nanoparticles for varistor studies. Mat Res Bull, 1993; 28:1303-10.

Jomova K, Valko M. Advances in metal-induced oxidative stress and human disease. Toxicology, 2011; 283:65-87.

Li N, Xia T, Nel AE. The role of oxidative stress in ambient particulate matter-induced lung diseases and its implications in the toxicity of engineered nanoparticles. Free Radical Bio Med, 2008; 44:1689-99.

Ma LL, Zhao JF, Wang J, Duan YM, Liu J, Li N, Yan J, Ruan $\mathrm{J}$, Wang $\mathrm{H}$, Hong $\mathrm{F}$. The acute liver injury in micecaused by nano-anatase $\mathrm{TiO}_{2}$. Nanoscale Res Lett, 2009; 4:1275-85.

Moosavi M, Goharshadi EK, Youssefi A. Fabrication, characterization, and measurement of some physicochemical properties of ZnO nanofluids. Int J Heat Fluid, 2010; 31:599-605.

Nair S, Sasidharan A, Divya Rani VV, Menon D, Nair S, Manzoor KS. Role of size scale of $\mathrm{ZnO}$ nanoparticles and microparticles on toxicity toward bacteria and osteoblast cancer cells. J Mater Sci Mater Med, 2009; 20:235-241

Nel A, Xia T, Madler L, Li N. Toxic potential of materials at the nanolevel. Science, 2006; 311:622-27.

Ohkawa H, Ohishi N, Yagi K. Assay for lipid peroxides in animal tissues by thiobarbituric acid reaction. Anal Biochem, 1979; 95:351-8.

Ostrovsky S, Kazimirsky G, Gedanken A, Brodie C. Selective cytotoxic effect of $\mathrm{ZnO}$ nanoparticles on glioma cells. Nano Res, 2009; 2:882-90.
Park EJ, Kimb H, Kimb Y, Yic J, Choid K, Park K. Inflammatory responses may be induced by a single intratracheal instillation of iron nanoparticles in mice. Toxicology, 2010; 275:65-71.

Park SJ, Park YC, Lee SW, Jeong MS, Yu KN, Jung H, Lee JK, Kim JS, Cho MH. Comparing the toxic mechanism of synthesized zinc oxide nanomaterials by physicochemical characterization and reactive oxygen species properties. Toxicol Lett, 2011; 207:197-203.

Premanathan M, Karthikeyan K, Jeyasubramanian $\mathrm{K}$, Manivannan G. Selective toxicity of $\mathrm{ZnO}$ nanoparticles toward Gram positive bacteria and cancer cells by apoptosis through lipid peroxidation. Nanomedicine NBM, 2011; 7:184-92.

Sánchez-Pérez Y, Chirino YI, Osornio-Vargas AR, MoralesBárcenas R, Gutiérrez-Ruíz C, Vázquez-López I, García-Cuellar CM. DNA damage response of A549 cells treated with particulate matter (PM10) of urban air pollutants, Cancer Lett, 2009; 278:192-200.

Scheringer M. Nanoecotoxicology: environmental risks of nanomaterials. Nat Nanotechnol, 2008; 3:322-3.

Sharma V, Shukla RK, Saxena N, Parmar D, Das M, Dhawan A. DNA damaging potential of zinc oxide nanoparticles in human epidermal cells. Toxicol Lett, 2009; 185:211-8.

Sharma V, Singh P, Pandey AK, Dhawan A. Induction of oxidative stress, DNA damage and apoptosis in mouse liver after sub-acute oral exposure to zinc oxide nanoparticles. Mutat Res, 2012; 745:84-91.

Van Herck H, Baumans V, Brandt CJ, Boere HA, Hesp AP, Van Lith HA. Blood sampling from the retro-orbital plexus, the saphenous vein and the tail vein in rats: comparative effects on selected behavioural and blood variables. Lab Anim, 2001; 35:131.

Wang JJ, Sanderson JSB, Wang H. Cyto- and genotoxicity of ultrafine $\mathrm{TiO} 2$ particles in cultured human lymphoblastoid cells. Mutat Res, 2007; 628:99-106.

Wang ZL. Splendid one-dimensional nanostructures of zinc oxide: a new nanomaterial family for nanotechnology. ACS Nano, 2008; 2:1987-92.

Wise JP, Goodale BC, Wise SS. Silver nanospheres are cytotoxic and genotoxic to fish cells. Aquat Toxicol, 2010; 97:34-41.

Wu YN, Chen DH, Shi XY, Lian CC, Wang TY, Yeh CS, Ratinac KR, Thordarson P, Braet F, Shieh DB. Cancer-cell-specific cytotoxicity of non-oxidized iron elements in iron core-gold shell NPs. Nanomedicine, 2011; 7:420-7.

Xu J, Shi H, Ruth M, Yu H, Lazar L, Zou B, Yang C, Wu A, Zhao J. Acute toxicity of intravenously administered titanium dioxide nanoparticles in mice. PLoS One, 2013; 8:1-6.

How to cite this article:

Kamel NN, Rizk MZ, Hozayen WG, Abdel-Hamid A-HZ. $\mathrm{ZnO}$ nanoparticles: Crosslink between cytotoxicity on liver cell lines and In Vivo biosafety on different mice organs. J Appl Pharm Sci, 2019; 9(S1):058-066. 